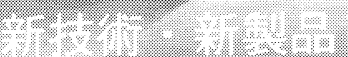

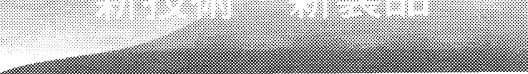

\section{赤外線加熱とコールドガスフローを併用した 広帯域温度連続スイープ型熱膨張計の開発}

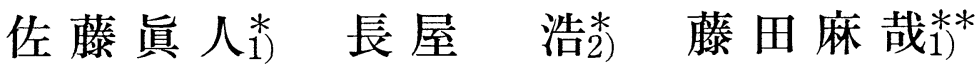 \\ 山内理恵光* 深道和明3
}

\section{1.は じめに}

最近の材料開発プロセスに和いては最終製品の微小化・高 精度化に伴ない, 材料自体の機能性の他に, 温度などの外場 に対する形状や体積変化への検討が重要になりつつある. 例 えば，薄膜デバイスの場合，材料と基板との熱膨張差に起因 する熱歪がデバイスの特性に著しい影響を与える(1).

磁性の基礎研究の分野では, 長年議論の的であった局在電 子モデルと遍歴電子モデルを統一するスピン摇らぎの理論が 守谷により提唱され(2), 各種磁性体でのスピンの摇らざの性 質の研究が進行している. スピンの摇らぎに関する情報は中 性子散乱や核磁気共鳴などの特殊設備を要する実験により得 られる場合が多いが，守谷の理論は熱膨張にもスピンの摇ら ぎに起因した異常が生じることを指摘している(2). 特に従来 の説明と異なる点は, 常磁性領域でも熱膨張異常が生じるこ とである。従って，精密な熱膨張測定はスピンの摇らぎに関 する重要な情報を提供する.

現在市販されている熱膨張計はセラミックスの焼結に伴う 体積収縮やガラス材料の軟化温度など巨視的な変化を高い温 度域で測定することが主眼とされているが，新機能材料の開 発では室温を中心とする温度範囲で高い精度を保ちつつ試料 の体積変化を計測することが要求される場合が多くなった。 特に連続的な温度制御の観点からは室温近傍は最も困難を伴

* 真空理工株式会社 $\mathrm{AE}$ 事業部：1)技術 2 課主任 2)設計課副 主任

** 東北大学大学院工学研究科 : 1) 学振研究員 2) 大学院生 3) 教授

Development of the Wide-Temperature Continuous SweepType Dilatometer Controlling by Infrared Radiation and ColdGas Flow; Masato Sato*, Hiroshi Nagaya*, Asaya Fujiya**, Rie Yamauchi**, Kazuaki Fukamichi**(*ULVAC SinkuRiko, Inc., ${ }^{* *}$ Tohoku University) 2000 年 1 月 7 日受理
ら領域であり，この点を最初から考慮して加熱・冷却方式を 設計しない限り室温近傍での精密測定は実現できない。 た，試料以外のバックグラウンド，例えば変位検出機構の熱 膨張などを広範囲の温度変化の中でどれだけ抑制できるかが 高精度測定を左右する。これらの問題を解決するため，赤外 線イメージ炉と液体窒素の気化ガスフローを温度制御に用い た押し棒式高感度熱膨張計を開発した。

\section{2. 開発技術の内容と特徵}

(1) バックグラウンドの低減

加熱・冷却機構との組み合わせのメリットを考慮し，熱膨 張検出法には縦型押し棒式を採用した。図 1 の装置模式図に 示した通り，加熱方式には赤外線イメージ炉を用いた. 図 2 には試料装着時にイメージ炉を開いた状態の写真を示す。困 中 $\mathrm{A}, \mathrm{B}, \mathrm{C}$ ，抢よび $\mathrm{D}$ はそれぞれ赤外線イメージ炉，試料， 押し棒执よび石英断熱 2 重管である.イメージ炉を用いた のは，試料外周の石英断熱 2 重管を通過した赤外線が主に 焦点近傍の試料に吸収され石英製押し棒自体の加熱を抑制す る効果を狙うためである.

試料は棒状めるいは板状であることを想定し，差動トラン スの線形入出力と炬の均熱帯の都合から試料長さは $10 \mathrm{~mm}$ が標準で $\pm 2 \mathrm{~mm}$ 程度のクリアランスを有する. 冷却方式と しては装置上端側にある試料のみを効率良く冷却するため に, 液体窒素デュワーからの気化冷凍ガスを装置上端から導 入した。 さらに，装置下部からは室温の不活性ガスを導入し 位置検出機構抢よび押し棒の温度変化を抑制した，実際の測 定時には試料および温度モニター用熱電対付近の空間が均一

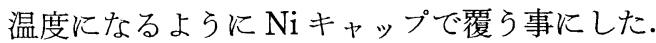

\section{（2）温度制御方式}

温度制御の方法として赤外線加熱のみに頼ると常に冷媒が 


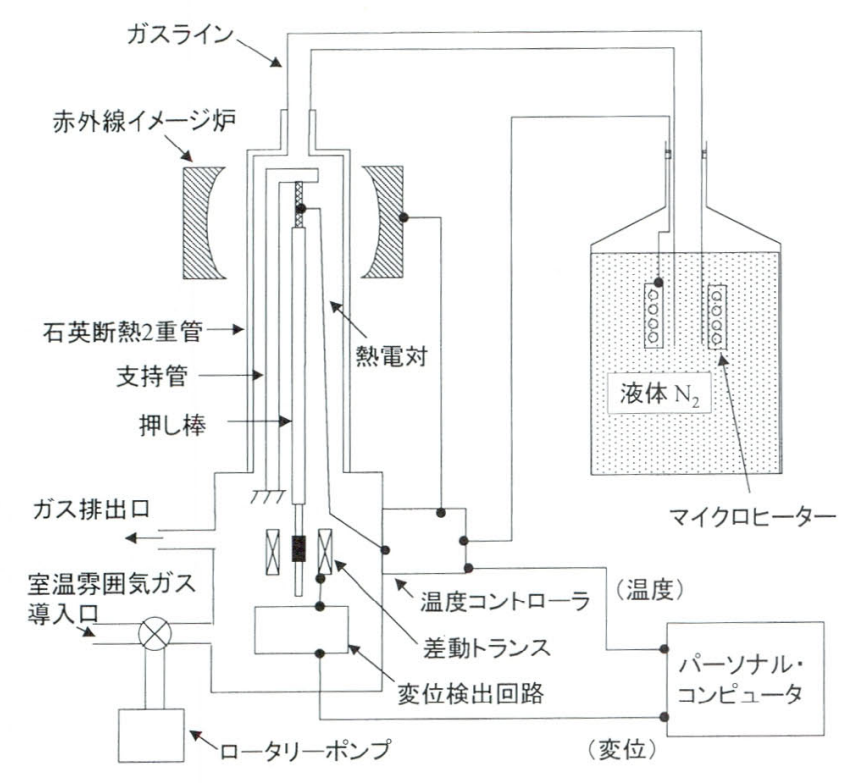

図 1 装置模式図.

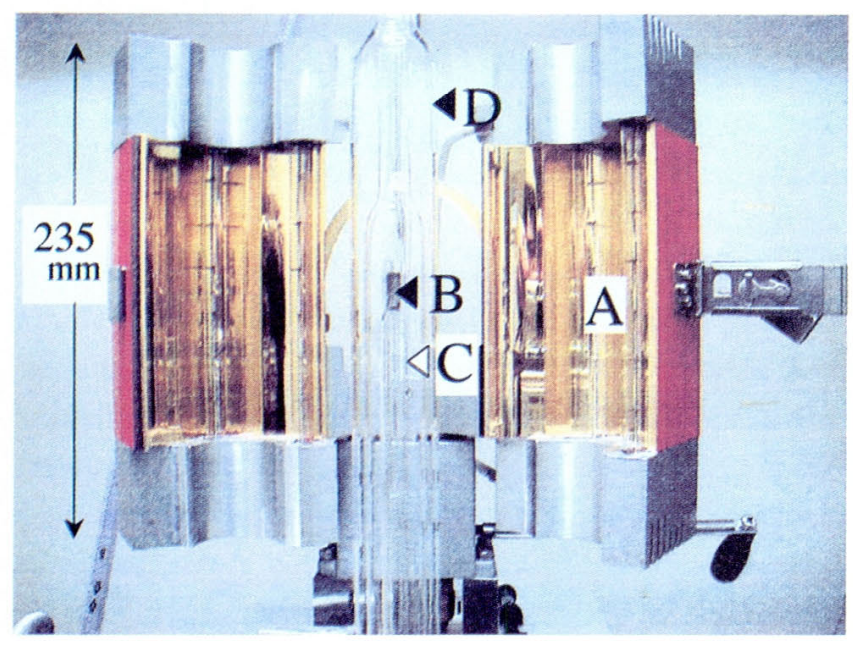

図 2 試料装着部付近の概観.
$\mathrm{A}$ ：赤外線イメージ炉，B：試料， C : 押乙棒,

D : 石英断熱 2 重管.

存在するため, 窒素温度付近から室温以上までの連続的な温 度変化は困難である。そこで(1)で述べた冷却効率を損なわな いで, 温度変化に対し冷却ガスの導入量を変化できるよう に, 窒素デュワー側のガスライン先端付近にマイクロヒータ 一を設置した，昇温時には温度コントローラが赤外線イメー ジ炉の出力を上げつつ, 逆にマイクロヒーターの出力を下げ ることで冷却ガス流量を減らす。この方法により, 適当な PID 定数を選べば $100 \mathrm{~K}$ 付近から室温をはさんで $1000 \mathrm{~K}$ 程度までの連続温度掃引が可能であり, さらには, 通常の温 度制御方式では困難な一定速度で冷却しながらの測定も可能 である。

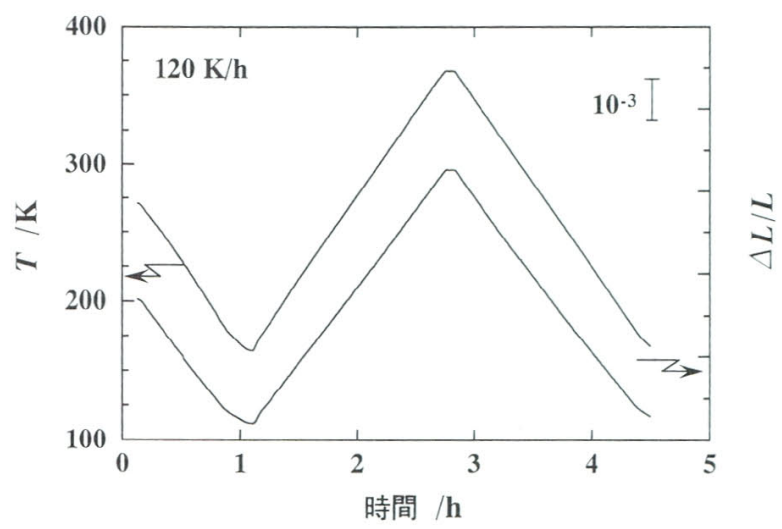

図 3 装置の温度特性 (試料 $\mathrm{A} 1$ ).

図 3 は $\mathrm{Al}$ 試料をセットして $100 \mathrm{~K}<T<400 \mathrm{~K}$ の範囲に 拈いて掃引速度 $120 \mathrm{~K} / \mathrm{h}$ の場合の温度制御特性をテストし た結果である. 赤外線加熱の特徵を反映して室温上下への昇 降温がスムーズに行われ，モニタ一温度変化に呼応して試料 熱膨張が速やかに追随し, 試料温度の制御が非常に容易であ ることがわかる。

\section{3. 適用例}

本熱膨張計の開発がいかに重要であるか, 実用拈よび基礎 的観点から典型的な 2 つ適用例を以下に示す.

\section{（1） スピンバルブ用反強磁性体 $\gamma-\mathrm{Mn}-\mathrm{Rh}$ 合金の熱膨張} 特性

最近の磁気ディスク再生ヘッドの主流である巨大磁気抵抗 効果 $(\mathrm{GMR})$ を基本とするスピンバルブヘッドには強磁性体 の磁化反転を制御するため反強磁性体が用いられる(3)。 $\mathrm{Mn}$-貴金属系反強磁性体は高いネール温度を有し, 薄い膜 厚でも良い特性が得られることが知られている。 スピンバル ブヘッド特性において重要な強磁性一反強磁性層間の交換結 合は歪敏感な性質を有して沶り (1)，形成プロセス中に反強磁 性膜と周囲との熱膨張差により生じる歪の制御が特性向上へ のキーポイントの一つとなるが, 実際に $\gamma-\mathrm{Mn}$-貴金属合金 の熱膨張特性を測定した報告例は少ない。

今回開発した熱膨張計を用い，スピンバルブ用反強磁性材 料の 1 つである $\gamma-\mathrm{Mn}_{75} \mathrm{Rh}_{25}$ 合金の熱膨張を計測した結果を 図 4 に示す，実線は熱膨張曲線であり，数值微分で得られた 線膨張係数も併せてプロットした. 図から明らかなように, ネール温度 $T_{\mathrm{N}}$ の上下で熱膨張の温度変化に差が生じて抗 り，蓺膨張に磁気的な寄与が含まれることがわかる. 本系の 磁気的な寄与の特徵は磁気秩序の発生に伴い体積が収縮す る, 寸なわら負の自発体積磁丕が生じることである。また， 線膨張係数は $T_{\mathrm{N}}$ 近傍で正側に発散しており, 体積変化が $T_{\mathrm{N}}$ 近傍で最も顕著に生じていることがわかる. 


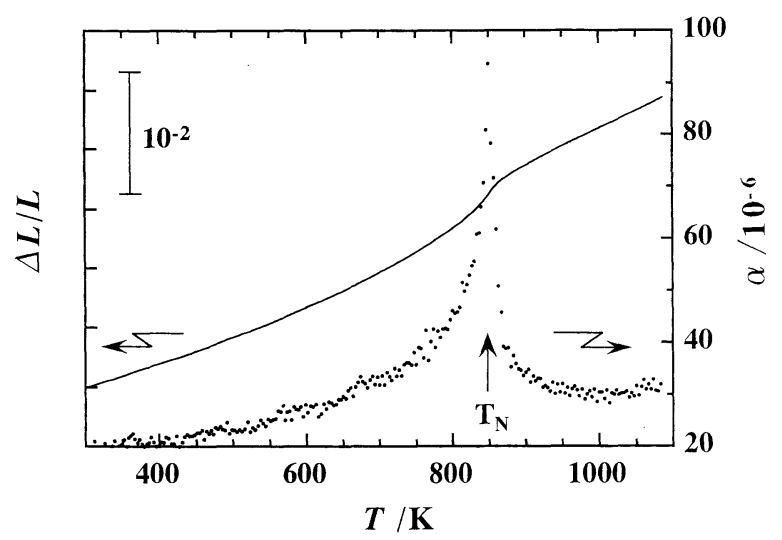

図 $4 \gamma-\mathrm{Mn}_{75} \mathrm{Rh}_{25}$ 規則合金の熱膨張曲線と線膨張係数 の温度変化.

自発体積磁歪の存在は同時に外部応力による体積変化が $T_{\mathrm{N}}$ に影響を及ぼすことを意味して牧り，スピンバルブヘッ ドの重要な特徵である交換結合の大ささに影響する(1). 従っ て，このよらな材料に扮いて熱膨張測定は非常に重要な検討 項目であり，本熱膨張計が薄膜デバイス開発において重要な 役割を果たすことがわかる.

\section{（2）遍歴電子メ夕磁性 $\mathrm{La}\left(\mathrm{Fe}_{x} \mathrm{Si}_{1-x}\right)_{13}$ 化合物の自発体積 磁歪}

磁気体積効果の研究では, 磁気転移温度の上下で広範囲に 渡り熱膨張測定を行う必要があるが，従来の熱膨張計のよう に室温以下と以上で個別に測定を行ら方式では, 磁気転移温 度が室温近傍の場合は測定が連続的に行えず，データの信頼 性の低下が不可避であった，今回開発した装置では室温近傍 での連続的な測定を主眼としているため, 磁気転移温度が室 温近傍でも精度を落とすことなく測定が可能になった。

$\mathrm{La}\left(\mathrm{Fe}_{x} \mathrm{Si}_{1-x}\right)_{13}$ 化合物は $x \geq 0.86$ に打いてキュリー温度 $(190 \sim 210 \mathrm{~K})$ で強磁性から常磁性への 1 次相転移を生じ る(4).さらに, キュリー温度直上で磁場を印加することで常 磁性から強磁性への磁場誘起相転移, いわゆる遍歴電子小夕 磁性転移を示す (4). 遍歴電子メ夕磁性転移は局所磁化の発生 ・消失を伴うため, 大きな体積変化が期待される. 実際に $x$ $=0.88$ の試料について行った熱膨張測定の結果を図 5 亿示 す。良好な温度追随のために転移温度 $T_{\mathrm{C}}$ で約 $1.2 \%$ によよ ぶ急激な体積変化が明瞭に観測される。な扣， $T_{\mathrm{C}}$ 直上でも 若干収縮が続いているが，常磁性温度領域に打けるこの挙動 は装置に起因するのではなくスピンの本質的な現象である. 本系の磁気体積効果においては磁気モーメントの発生・消失 に加壳，スピンの摇らぎの影響が顕著であることを示す貴重

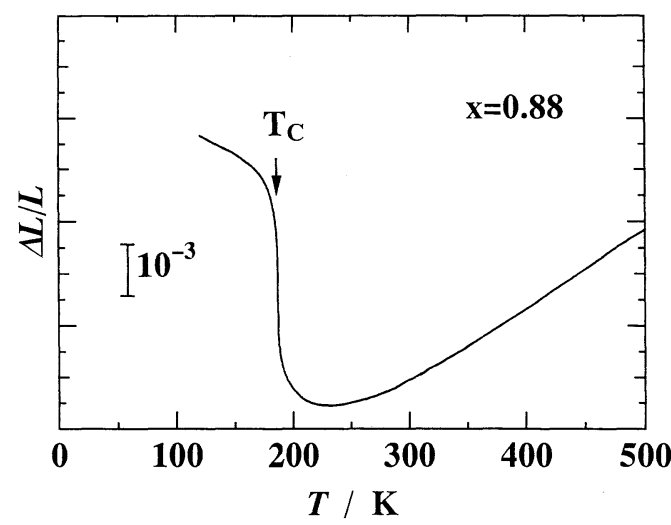

図 $5 \mathrm{La}\left(\mathrm{Fe}_{0.88} \mathrm{Si}_{0.12}\right)_{13}$ 化合物の熱膨張曲線.

なデータである。また， $T_{\mathrm{C}}$ 以上で体積が膨張する温度域で も格子振動に加光スピンの摇らぎの寄与が存在することが知 られており, 遍歴電子磁性体では常磁性温度領域での熱膨張 測定も重要な意味を有する。注目すべきは図 5 に見られる ように，体積膨張が始まる温度が室温に近いにもかかわら ず，本熱膨張計ではスムーズなデータが得られることでめ り，スピンの摇らぎに関する情報を得る上で信頼性の高い解 析が可能となる事がわかる，以上のように，本熱膨張計は応 用材料開発ばかりではなく，物性研究の分野でも重要な貢献 を果たす事が示された。

\section{4. まと め}

先進デバイス開発や基礎物性研究に有益な, 広温度範囲で 精密測定可能な熱膨張計を開発した. 特に従来困難な低温か ら室温を経て高温域までを連続的に温度スイープできる温度 制御システムを搭載しつつ, 熱膨張計本来の精度を失うこと なく測定を可能にした。本稿では実用材料および物理的に興 味深い材料への典型的な適用例を示したが, いずれも満足で さるデータが得られている. 従って, 本装置開発は様々な分 野で貢献することが期待される。

\section{文献}

（1）及川勝成: 私信.

(2) T. Moriya: Spin Fluctuations in Itinerant Electron Magnetism, Solid State Sciences 56, Springer-Verlag, Berlin, (1985).

（3）日本応用磁気学会 : 第99回研究会資料, (1997).

(4) A. Fujita, Y. Akamatsu and K. Fukamichi: J. Appl. Phys., 85 (1999), 4756 